\section{Salts Deposited on the Lower Stem of Bell Pepper Contribute to a Basal Stem Disorder in Soilless, Greenhouse- grown Plants}

\author{
Elio Jovicich ${ }^{1}$ and Daniel J. Cantliffe ${ }^{2}$ \\ Horticultural Sciences Department, 1241 Fifield Hall, P.O. Box 110690, \\ University of Florida, Gainesville, FL 32611-0690
}

Additional index words. Capsicum annuum, transplant depth, irrigation, physiological disorder, stem rot, Fusarium

\begin{abstract}
A physiological disorder in greenhouse-grown pepper (Capsicum annuum L.) plants was observed in Florida, wherein the base of the main stem becomes swollen below the cotyledonary node level and crack-like wounds develop at the base of the stem's epidermis. The disorder may predispose the plant to a localized rot and result in a sudden plant wilt. The effects of soilless media type, transplant depth, and amount of nutrient solution applied per day were studied to evaluate the development of what was termed "Elephant's Foot" disorder, on a greenhouse-grown bell pepper crop in Gainesville, Fla. The percentage of plants with epidermal wounds at the base of the stem was highest $(83 \%)$ on plants transplanted at half of the cell height $(3.8 \mathrm{~cm})$, compared to plants transplanted to the cotyledonary node level $(6 \%)$ and the second leaf node $(0 \%)$. Salts were washed from the surface of basal stem epidermis and electrical conductivity measured in the washing solution was expressed per unit area of epidermal sample (ECA). The ECA in the solutions from plants transplanted at half of the cell height was higher than that from plants transplanted to the cotyledonary node level and to the second leaf node. There was a positive linear relationship $(r=0.81)$ between the percentage of plants with epidermal wounds and the ECA of the solution obtained from washing the epidermal tissues. Salts deposited on the epidermis beneath the cotyledonary node provoked a tissue injury that may predispose the plant to a $F$ usarium infection. Simple management practices, such as transplanting deep, using cultivars with lower susceptibility to salt damage, and gradually moving back the emitter from the base of the plant after transplanting (to reduce humid conditions near the base of the stem) would help reduce the appearance of this basal stem disorder in soilless-grown peppers.
\end{abstract}

Greenhouse production of colored bell pepper is a small but expanding industry in Florida (Tyson et al., 2001). As with other high value greenhouse crops (i.e., tomato, cucumber, and melon), soilless culture is an alternative to traditional soil cultivation and is predicted to be the main production method after banning of methyl bromide in 2005 (Cantliffe and Vansickle, 2001; Cantliffe et al., 2001). Pepper crops are grown in containers with soilless media, such as perlite, peat, pine bark, or combinations of these substrates. A complete nutrient solution is used to water and fertilize plants with each irrigation event. Although with the use of soilless culture the incidence of soilborne diseases may be minimized, inadequate management of water and fertilizer may lead to physiological disorders that might predispose plants to secondary pathogen infections (Jarvis, 1997).

Symptoms of plant wilt were observed in greenhouse-grown pepper plants in 1998 and

Received for publication 22 Nov. 2002. Accepted for publication 19 June 2003. Florida Agricultural Experiment Station Journal Series R-09104. We thank C.M. Stiles, E.H. Simonne, and P.J. Stoffella for reviewing early versions of this manuscript. ${ }^{1}$ Graduate Student. E-mail: jovicich@ufl.edu

${ }^{2}$ Professor and Chairman; to whom reprint requests should be addressed.E-mail: djc@mail.ifas.ufl.edu
1999 in Gainesville, Fla. (Jovicich etal., 1999). Temporary or permanent plant wilt was first observed $39 \mathrm{~d}$ after transplanting (DAT) in a fall crop (25 Nov. 1998) and 52 DAT in a spring crop (10 Mar. 1999) (Fig. 1A). Before wilting started in the perlite-grown plants of both the spring and fall crops, the plants developed a swelling of the stem just below the cotyledonary node. Stem diameter increased $15 \%$ to $20 \%$ as compared with plants that did not exhibit the symptom. Along with the swelling at the base of the stem, longitudinal wounds also appeared at the base of the plant (Fig. $1 \mathrm{~B}$ and C). Plants that presented these symptoms first wilted temporarily during the afternoon, especially when periods of high temperatures created a high demand for water in the plant. Wilted plants randomly appeared throughout the greenhouse. Some plants became swollen on the base of the stem but did not wilt or die. The same symptoms were observed in plants grown at commercial greenhouse operations in Florida during Spring 1999, with the disorder affecting nearly $70 \%$ of the plants in one case (Burnac Greenhouses, Ft. Pierce, Fla.; growing area $\approx 11$ ha).

In greenhouse-grown pepper crops that ended with a plant wilt (Jovicich et al., 1999), Fusarium oxysporum was found in the base of stems with epidermal wounds tested for pathogenic organisms (Florida Extension Plant Disease Clinic, Inst. Food Agr. Sci., Plant Pathology Dept., Univ. of Florida). These wounds on the epidermis allow an entry to the opportunist vascular-wilt fungi, whose mycelium can reach the xylem and invade the vessels through the xylem pits (Agrios, 1997). Browning of the vascular tissue was commonly observed in longitudinal sections of the basal stems (Fig. 1D).

The symptoms of basal stem swelling and epidermal wounds have also been reported in greenhouse-grown pepper plants in Italy (Cartia et al., 1988; Matta and Garibaldi, 1980) and Spain (Morató, 1996). In each location, the basal stem swelling and epidermal wounds were restricted to the region below the cotyledonary nodes. In Italy, Matta and Garibaldi (1980) reported that temporary water logging caused the "foot corkiness" of soil-grown pepper. This same disorder was reported to be common in Sicily, reaching $60 \%$ of total plants with basal stem rot (Cartia et al., 1988). Morató (1996), in Spain, reported a similar physiological disorder, named bell pepper "basal stem rot," developed as a plant response from a localized area with high humidity and lack of aeration around the stem base. He differentiated the disorder from a root anoxia caused by a general soil flooding that also results in a root rot and subsequent plant wilt. Spanish greenhouse growers from the Murcia region have coined this disorder in pepper plants with the name "Elephant's Foot," based on a description of the lower stem appearance (Jovicich et al., 1999). Factors that may contribute to the cause of the disorder are not known. Morató (1996) reported that the basal stem rot can be caused by a constant or frequent drip of solution due to the proximity of the irrigation tubing to the stem base. However, epidermal injuries on the base of the stem may be a plant response to salt accumulation (based on observations of white crystals on the stem base) and/or excess of humidity.

We investigated the effects of different daily nutrient solution volumes, soilless media, and transplant depths on salt accumulation and damage of the epidermis at the stem base of pepper plants. It was of interest to determine: 1 ) if transplant depth could be used as a practice to reduce or avoid epidermal wounds on the stem epidermis at the surface of the soilless media; 2 ) the response of volume of nutrient solution applied daily on salt accumulation and epidermal damage at the base of the stem; and 3) if four commercially used growing media would have a different response on epidermal salt deposition and the appearance of the disorder at the stem base. The identification of factors that would reduce or avoid the "Elephant's Foot" disorder will improve management practices in soilless-grown bell pepper.

\section{Materials and Methods}

Seedlings of bell pepper 'Kelvin' (De Ruiter Seeds, Bergschenhoek, Holland) were grown on a $70 \%$ peatmoss : $30 \%$ vermiculite (v/v) substrate mix (Terra-Lite Plug Mix, Terra Asgrow, Apopka, Fla.) in 200-cell (width $\times$ 


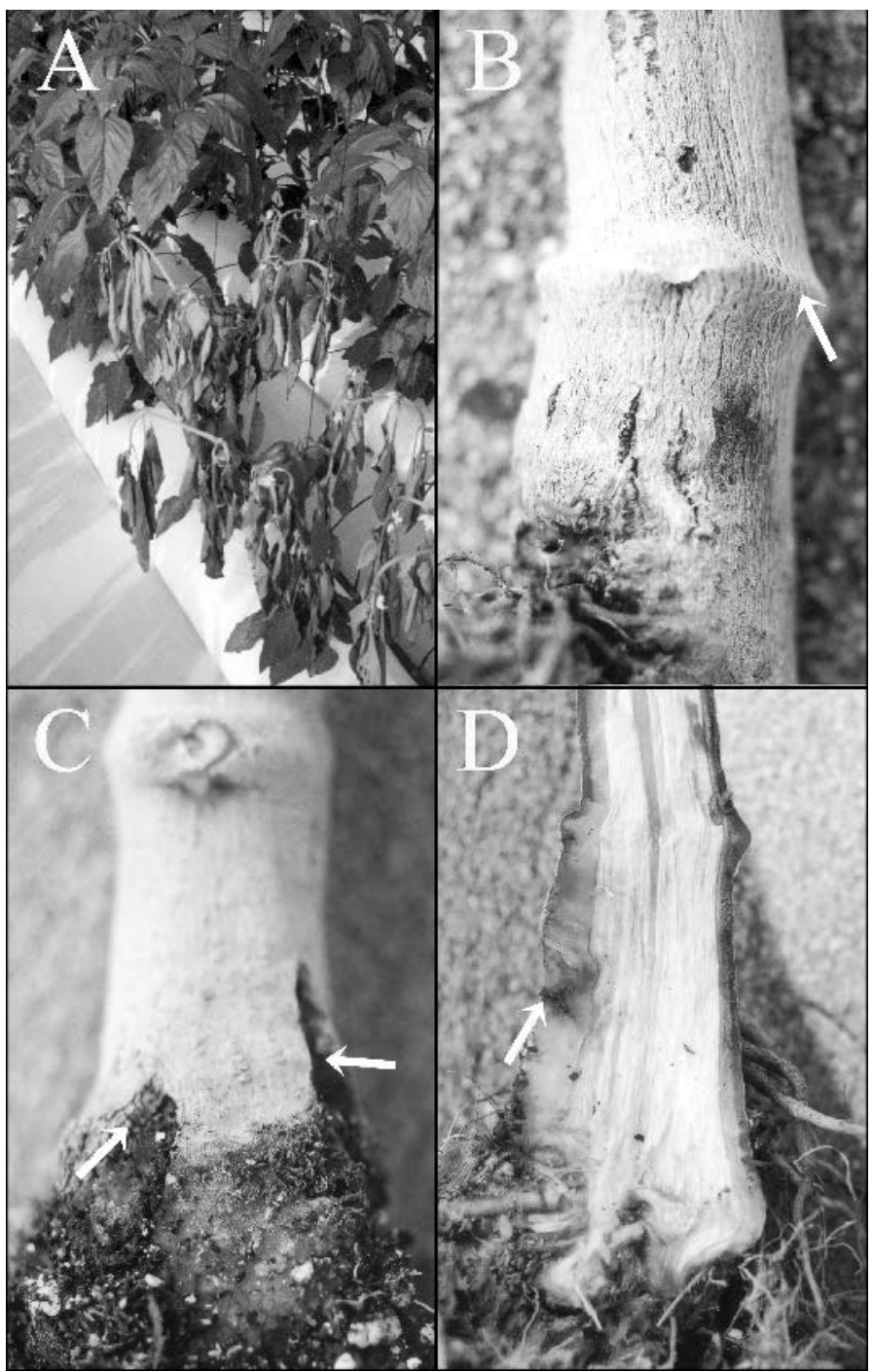

Fig. 1. Symptoms observed in soilless-grown pepper plants (Nov. 1998 and Mar. 1999, Gainesville, Fla.) with basal stem disorder: (A) plant wilt in plants grown in bags filled with perlite; (B) early swelling of the base of the stem and wounds on the epidermis below the cotyledonary node (arrow); (C) longitudinal crack-like wounds (arrows) at the base of the stem; and (D) longitudinal section of the base of the stem with necrosis in the tissues near the wound (arrow).

width $\times$ height: $2.5 \times 2.5 \times 6.5 \mathrm{~cm})$ polystyrene transplant flats (Speedling, Sun City, Fla.). After 35 d (19 June 1999), the seedlings were transplanted from the polystyrene flats into $7.6 \times 7.6 \times 8.3-\mathrm{cm}($ side $\times$ side $\times$ height $)$ polyethylene containers $\left(475 \mathrm{~cm}^{3}\right.$, model VSR325; Lerio Corp., Kissimmee, Fla.) with the same substrate. Depth of transplanting in these containers was at the cotyledonary node level. Once planted into the containers, seedlings were irrigated once per day with a solution with nutrient levels $\left(\mathrm{mg} \cdot \mathrm{L}^{-1}\right)$ of $\mathrm{NO}_{3}^{-}$ $\mathrm{N}: 70$, P: 50, and K: 120 . On 29 June 1999 , 45-day-old seedlings grown for $10 \mathrm{~d}$ in the containers were transplanted into cylindrical $11.3-\mathrm{dm}^{3}$ polyethylene pots (model A-30; Lerio Corp., Kissimmee, Fla.) at three transplant depths: 1) at half of the container height (3.8 $\mathrm{cm}$ ), cutting and discarding only the bottom of the container; 2) at the cotyledonary node level; and 3 ) at the second leaf node, $\approx 3.0 \mathrm{~cm}$ above the cotyledonary node (Fig. 2).

Each plant was irrigated with a pressurecompensated irrigation emitter with a flow discharge of $2 \mathrm{~L} \cdot \mathrm{h}^{-1}$ (Netafim, Altamonte Springs, Fla.). The position of the irrigation emitter stakes with respect to the base of the stem was changed only in plants transplanted with the bottomless container. In these plants, the emitter stake was placed $2.5 \mathrm{~cm}$ away from the base of the stem and on top of the bottomless container at transplanting, and it was moved at the side and bottom of the bottomless containers 21 DAT (when roots had grown into the pot media) (final position of the emitter stake is depicted in Fig. 2). The irrigation emitter stakes in plants transplanted to the second leaf node and in those transplanted to the cotyledonary node depth were not moved from their initial placement $(2.5 \mathrm{~cm}$ away from the base of the stem) (Fig. 2)

During the first 16 DAT, plants were irrigated with the same irrigation schedule in order to uniformly establish all plants in the pots. During this period, the amount of nutrient solution per plant per day was $0.8 \mathrm{~L}$ until 5 July (6 DAT), followed by $1.4 \mathrm{~L}$ until 10 July (12 DAT), and 2 L until 19 July (20 DAT). Five irrigation treatments were started on 20 July (21 DAT). Plants were irrigated during daylight, with the same frequency (34 times per day, from 6:00 AM-8:00 PM) but with different irrigation periods in order to provide daily volumes of $2,2.5,3,3.5$, and $4 \mathrm{~L}$ of nutrient solution per plant. A time-based irrigation controller was used to schedule the irrigation events (Pro Rain, Antelco Corp., Longwood, Fla.).

Irrigation and transplant depth treatments were tested in four soilless media: 1) perlite of "horticultural grade" (Airlite Processing Corp. of Florida, Vero Beach); 2) coconut coir (ScottsSierra Horticultural Products Co., Marysville, Ohio); 3 ) a mix of $60 \%$ peat : $20 \%$ vermiculite : $20 \%$ perlite (v/v) (Speedling, Bushnell, Fla.); and 4) pine bark (Pinus sp.), not composted and screened through a mesh of $2.5-\mathrm{cm}$ squares (Elixon Wood Products, Starke, Fla.).

Plants were irrigated with a complete nutrient solution with nutrient concentration levels developed for greenhouse-grown hydroponic tomatoes (Hochmuth, 1991) and adapted for pepper plant developmental stages in this experiment. Nutrient levels $\left(\mathrm{mg} \cdot \mathrm{L}^{-1}\right)$ from transplanting until 15 July (16 DAT; fruit set on third-order nodes), were $\mathrm{NO}_{3}{ }^{-} \mathrm{N}: 80, \mathrm{P}: 50$, $\mathrm{K}: 120$, Ca: $127, \mathrm{Mg}: 40, \mathrm{~S}: 56$, and electrical conductivity (EC): $1.4 \mathrm{mS} \cdot \mathrm{cm}^{-1}$. From 15 July, when irrigation treatments were started, to 1 Aug. (33 DAT, second fruit set on fifth- to seventh-order nodes), nutrient levels $\left(\mathrm{mg} \cdot \mathrm{L}^{-1}\right)$ were $\mathrm{NO}_{3}^{-}-\mathrm{N}: 100$, P: 50, K: 148 , Ca: 143 , $\mathrm{Mg}: 40, \mathrm{~S}: 56$, and $\mathrm{EC}$ was $1.8 \mathrm{mS} \cdot \mathrm{cm}^{-1}$. After 1 Aug., levels were $\mathrm{NO}_{3}{ }^{-}-\mathrm{N}: 120, \mathrm{P}: 50, \mathrm{~K}$ : 174, Ca: $143, \mathrm{Mg}: 48, \mathrm{~S}: 66 \mathrm{mg} \cdot \mathrm{L}^{-1}$, and EC: $2.0 \mathrm{mS} \cdot \mathrm{cm}^{-1}$. The $\mathrm{pH}$ in the final solution was maintained between 5.8 and 6.5. Two fertilizer proportional injectors [Model DI 16-11 $\mathrm{gal} \cdot \mathrm{min}^{-1}\left(60.5-41.6 \mathrm{~L} \cdot \mathrm{min}^{-1}\right)$, Dosatron International, Clearwater, Fla.] placed in series were used to pump concentrated stock solutions into the water at every irrigation event.

Pepper plants were grown in a single bay $(8 \times 32 \times 9 \mathrm{~m}$, width $\times$ length $\times$ height, respectively) of a seven-bay passive-ventilated greenhouse (Top Greenhouses Ltd., Rosh Ha'ayin, Israel), north-south oriented, located at the Horticultural Sciences Protected Agriculture Center, Univ. of Florida, in Gainesville. Pots were aligned in double rows with $1.6 \mathrm{~m}$ between centers of the rows $\left(4.2 \mathrm{plant} / \mathrm{m}^{2}\right)$. The experimental design was arranged as split-split plot with three blocks (on the north, center, and south area of the greenhouse bay) and with four plants in each plot. Irrigation volume was the main plot, transplant depth was the subplot, and medium type was the sub-subplot.

Each plant was pruned only twice to leave two main stems after the crown flower, which was pulled from the plants together with the second-order flowers to encourage vegetative growth. Plants were supported with lateral horizontal plastic twines, which were separated at heights of $30 \mathrm{~cm}$ and tied to iron stakes driven into the ground along the plant rows. This trellis system was similar to that used in soil-grown pepper plants in southern Spain (Nuez et al., 1996), and has been used for soilless-grown peppers in Florida (Jovicich and Cantliffe, 2001) 
TRANSPLANT DEPTHS

a) I lalf container height

b) Cotyledonary node

c) Second leaf node

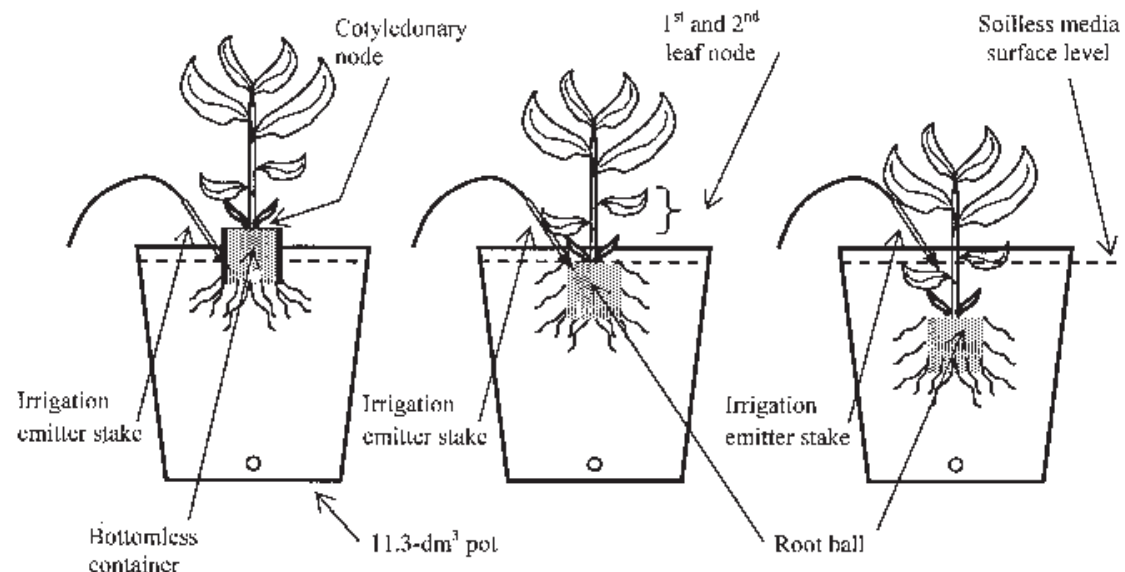

Fig. 2. Transplant depth treatments and the irrigation emitter stakes position at 21 DAT: (a) pepper plants transplanted into pots to half of the polyethylene container height with the bottom of the container removed; (b) plants transplanted with the root ball to the cotyledonary node level; and (c) plants transplanted with the root ball to the second leaf node.

On 25 Nov. (149 DAT), the percentage of plants with "Elephant's Foot" symptoms (crack-like wounds on the stem epidermis at the surface of the soilless media level) was visually determined. Salt accumulation at the base of the stem was determined by measuring EC of a solution obtained by washing a sample of epidermal tissue taken from the lower part of the stem. The base of the plant stem was severed at the surface of the soilless media level, and a 25-mm-long cylinder of epidermal tissue was peeled with a grafting knife from the end portion close to the soilless medium. The stem diameter on the upper portion of the epidermal cylinder was measured with a caliper, and the area was calculated as follows: epidermal sample area $\left(\mathrm{mm}^{2}\right)=$ stem diameter $(\mathrm{mm}) \times 25$ $(\mathrm{mm}) \times 3.14$. The epidermal sample was placed in a cup with $20 \mathrm{~mL}$ of deionized water (EC: $0.005 \mathrm{mS} \cdot \mathrm{cm}^{-1}$ ), stirred in water for $1 \mathrm{~min}$ and after 3 more minutes, EC was measured with a portable electrical conductivity meter (Twin Cond B-173, Horiba, Kyoto, Japan). Measured EC values were expressed on an epidermal area basis (ECA, units in $\mathrm{mS} \cdot \mathrm{cm}^{-1} \cdot \mathrm{mm}^{-2}$ ) in order to relate accumulated salts to the epidermal area exposed at the surface of the media level. Two plants per plot were used for the salt accumulation determination.

Analyses of variance (ANOVA) were performed on the ECA measurements and on the percentage of plants with basal stem swelling and epidermal damage symptom observations (SAS, 1999). Volume of irrigation per day was considered a continuous variable while transplant depth and soilless media type were considered discrete variables. Percentages of plants with wounds on the epidermis were arcsin-transformed prior to conducting the ANOVA. Correlation analysis was performed between ECA and percentage of plants with basal stem swelling and epidermal damage symptoms. Volume of irrigation response was analyzed for its polynomial effects (SAS, 1999). Treatment means were compared us- ing the least significant difference (LSD) mean separation method. Appropriate standard error terms for mean comparison or polynomial effect tests were calculated using formulae given by Cochran and Cox (1957).

\section{Results and Discussion}

The highest percentage of plants with wounded epidermis $(83 \%)$ was observed on transformed means are presented. the plants transplanted to half of the container height (Table 1). The percentage of plants where the disorder symptoms were significantly lower $(6 \%)$ occurred in the plants transplanted to the cotyledonary node level, while plants transplanted to the depth of the second leaf node did not exhibit any damage on the epidermis at the surface of the media level. When stems of the plants transplanted to the second leaf node were uncovered, no apparent damage on the epidermal tissue and swelling at the hypocotyl region could be observed. However, the development of some hypertrophied lenticels was observed on the buried epidermis above the cotyledonary node level. The percentage of plants with basal stem epidermal damage was not significantly different among irrigation and media treatments, nor were any interactions significant (Table 1).

Salts on the epidermis at the surface of the media (measured as ECA), accumulated to a greater level under irrigation treatments with higher volumes of solution applied per day (Table 1). The linear response of ECA for increased volumes of nutrient solution existed with all media types and transplant depths, as interactions with the irrigation treatment were nonsignificant (Table 1).

Epidermal samples from plants transplanted to half of the container height had significantly higher ECA values ( $40 \%$ to $50 \%$ ) than plants transplanted to the second leaf node or to the cotyledonary node depth (Tables 1 and 2). The location of the irrigation emitter on the bottom and side of the bottomless polyethylene container (Fig. 2) created a greater evaporation

Table 1. Main effect means of bell pepper plants with epidermal damage at the base of the stem (\%) and for the electrical conductivity of the solution (ECA) after epidermal samples at the base of the stem were washed with de-ionized water.

\begin{tabular}{|c|c|c|}
\hline Treatments ${ }^{\mathrm{x}}$ & $\begin{array}{l}\text { Epidermal damage }^{\mathrm{z}} \\
(\%)\end{array}$ & $\begin{array}{c}\mathrm{ECA}^{\mathrm{y}} \\
\left(\mathrm{mS} \cdot \mathrm{cm}^{-1} \cdot \mathrm{mm}^{-2}\right)\end{array}$ \\
\hline \multicolumn{3}{|l|}{ Irrigation $\left(\mathrm{L} \cdot \mathrm{d}^{-1}\right.$ per plant) } \\
\hline 2 & 21.5 & 0.672 \\
\hline 2.5 & 29.7 & 0.730 \\
\hline 3 & 33.3 & 0.855 \\
\hline 3.5 & 25.4 & 0.916 \\
\hline \multirow[t]{2}{*}{4} & 37.5 & 0.962 \\
\hline & NS & $\mathrm{L}^{* *}$ \\
\hline \multicolumn{3}{|l|}{ Depth } \\
\hline Half the container height & $82.6 \mathrm{a}$ & 1.230 \\
\hline Cotyledonary node & $5.9 \mathrm{~b}$ & 0.626 \\
\hline \multirow[t]{2}{*}{ Second leaf node } & $0 \mathrm{c}$ & 0.625 \\
\hline & $* *$ & $* *$ \\
\hline \multicolumn{3}{|l|}{ Media } \\
\hline Peat mix & 26.1 & 0.856 \\
\hline Coconut coir & 32.8 & 0.790 \\
\hline Perlite & 27.8 & 0.808 \\
\hline \multirow[t]{2}{*}{ Pine bark } & 31.1 & 0.854 \\
\hline & NS & $* *$ \\
\hline \multicolumn{3}{|l|}{ Interactions } \\
\hline Irrigation $(\mathrm{I}) \times$ Depth $(\mathrm{D})$ & NS & NS \\
\hline $\mathrm{I} \times \operatorname{Media}(\mathrm{M})$ & NS & NS \\
\hline $\mathrm{D} \times \mathrm{M}$ & NS & $* * \mathrm{w}$ \\
\hline $\mathrm{I} \times \mathrm{D} \times \mathrm{M}$ & NS & NS \\
\hline
\end{tabular}

${ }^{2}$ Percentage based on number of plants with symptoms of epidermal wounds. Statistical analysis performed on arcsin transformed data. Means followed by different letter are significantly different, based on LSD test on transformed means $(\alpha=0.05)$. Non-

${ }^{y} \mathrm{ECA}$ is EC of the washing solution expressed per unit area of epidermal sample.

xPlants were irrigated with five daily volumes (Irrigation), transplanted to three planting depths (Depth), and grown in four types of media (Media).

weans of ECA for the Depth $\times$ Media interaction are presented in Table 2.

NS, *** Nonsignificant or significant at $P<0.05$ and 0.01 , respectively; $\mathrm{L}=$ linear. 
Table 2. Electrical conductivity (ECA) measured in the solution after epidermal samples at the base of the stem of bell pepper were washed with de-ionized water from plants grown in four types of soilless media and transplanted at three depths.

\begin{tabular}{lccccc}
\hline & \multicolumn{5}{c}{$\mathrm{ECA}^{\mathrm{z}}\left(\mathrm{mS} \cdot \mathrm{cm}^{-1} \cdot \mathrm{mm}^{-2}\right)$} \\
\cline { 2 - 5 } Depth & Media: & Coconut coir & Peat mix & Perlite & Pine bark \\
\hline Half container height & 1.330 & 1.078 & 1.169 & 1.345 & $\mathrm{LSD} 1^{\mathrm{y}}=0.086$ \\
Cotyledonary node & 0.627 & 0.614 & 0.615 & 0.648 & $\mathrm{mS} \cdot \mathrm{cm}^{-1} \cdot \mathrm{mm}^{-2}$ \\
Second leaf node & 0.610 & 0.677 & 0.641 & 0.570 & \\
& \multicolumn{5}{c}{ LSD $2^{\mathrm{x}}=0.126 \mathrm{mS} \cdot \mathrm{cm}^{-1} \cdot \mathrm{mm}^{-2}$} \\
\hline
\end{tabular}

${ }^{\mathrm{z}} \mathrm{ECA}$ is EC of the washing solution expressed per unit area of epidermal sample.

${ }^{y_{L S D}} 1$ is for comparisons of media types within planting depths (MSE $=0.014 ; \mathrm{df}=90 ; \mathrm{SE}=0.043$ ).

${ }^{\mathrm{x}}$ LSD 2 is for comparisons of planting depths within media types or across planting depth with different media types $(\mathrm{MSE}=0.029 ; \mathrm{df}=45.5 ; \mathrm{SE}=0.062)$.

at the top of this container, mainly through a "wick" effect that led to high levels of salts concentrated on the top of the bottomless container and, consequently, around the basal stem (cotyledonary) region. In the two treatments where the root ball was planted directly into the soilless media and irrigation emitters were placed at $2.5 \mathrm{~cm}$ from the base of the stem, irrigation might have leached salts, creating a lower salt concentration on the surface of the pot media and around the base of the stem.

The soilless media type had little effect on the level of salt deposited at the stem base (Table 2). In plants transplanted with the bottomless container to half of the container height, the ECA was lowest when peat mix was the growing media while in plants with the root ball planted to the second leaf node, the lowest ECA values were measured when the medium was pine bark (Table 2).

In this study, treatments with a high percentage of plants with basal stem epidermal damage corresponded with high values of ECA in the solution that washed the stem base. A positive linear relationship $(r=0.81)$ was obtained between ECA values and the percentage of plants with epidermal damage when all treatment data $(n=180)$ were considered. All plants transplanted to the second leaf node, which had no stem epidermal damage at the surface of the media level, had ECA values lower than $1.3 \mathrm{mS} \cdot \mathrm{cm}^{-1} \cdot \mathrm{mm}^{-2}$. Treatments with higher epidermal ECA and high percentage of plants with epidermal damage $(>75 \%)$ corresponded to plants transplanted with the polyethylene container to half of the cell height.

Salt levels at the basal stem were associated with the occurrence of epidermal wounds at this region. A localized direct salt injury can occur due to high deposition of salts on the epidermis at the base of the stem (Kozlowski, 2000; Levitt, 1972) and may be a major factor involved in the development of the "Elephant's Foot" disorder. In our experiment, epidermal wounds at the base of the stem appeared 149 DAT, but unlike previous crops (Jovicich et al., 1999), plants did not exhibit Fusarium wilt symptoms. However, high levels of salts near the base of the stem have been reported to induce swelling of the hypocotyl and damage of the epidermis, which predisposed the plants to Fusarium infections (Howard et al., 1994; Miyamoto et al., 1985; Standaert et al. 1978).

Transplanting the root ball into the pot media to the cotyledonary level resulted in a small percentage of plants with epidermal damage despite ECA values that were comparable to those in plants transplanted to the second leaf node depth. Leaf node epidermal wounds were avoided when pepper plants were transplanted to the second leaf node. Thus, future research might determine whether there is a differential sensitivity to salts on the epidermal region above and below the cotyledonary level. Deep root ball burial when transplanting pepper has been reported to improve plant establishment and to increase early yields in open-field crops (Mangan et al., 2000; Vavrina et al., 1994; 1996). We observed that transplanting to the first leaf node had the same positive response as had transplanting to the second node (Jovicich, 2001). It was noted that pepper cultivars could have a differential susceptibility to the basal stem disorder (Jovicich, 2001). In addition, gradually moving back the emitter from the base of the plant after transplanting (to reduce humid conditions near the base of the stem) helped to reduce the appearance of the disorder in soilless-grown peppers (Jovicich, 2001; Jovicich et al., 1999).

Salts which accumulate on the top of the media as a result of evaporation can deposit at the base of the pepper plant stem to levels that cause localized epidermal injuries. The level of salts deposited around the base of the stem might depend on the volume and concentration of nutrient solution applied and on the placement of the emitter with respect to the transplant, as salts usually concentrate on the wet and dry boundary area of the soilless media. Injury levels may be reached after a period of time as a consequence of wet and dry conditions from repeated irrigation cycles. Growing practices that lead to increased salt deposit around the base of the stem may adversely affect the base of the stem epidermis. More severe damage may occur in plants transplanted to the cotyledonary node than in plants transplanted to the first or second leaf node due to the physical makeup of the tissues in those areas. Transplanting the seedling with the cotyledonary node under the soilless media surface may be a simple management practice to avoid the development of the "Elephant's Foot" disorder in hydroponic greenhouse bell pepper without any subsequent problems associated with plant growth or fruit production.

\section{Literature Cited}

Agrios, G.N. 1997. Plant pathology. 4th ed. Academic Press, N.Y.

Cantliffe, D.J., N. Shaw, E. Jovicich, J.J Rodriguez, I. Secker, andZ. Karchi. 2001. Passive-ventilated high-roof greenhouse production of vegetables in a humid, mild winter climate. Acta Hort. 559:195-201.

Cantliffe, D.J. and J.J. Vansickle. 2001. Competitiveness of the Spanish and Dutch greenhouse industries with the Florida fresh vegetable industry. Proc. Fla. State Hort. Soc. 114:283-287.

Cartia, G., T. Cipriano, and M. Napoli. 1988. Osservazioni sulla eziologia di una necrosi basale del peperone. Colture Protette 1:71-75.

Cochran, W.G. and G.M. Cox. 1957. Experimental designs. 2nd ed. Wiley, N.Y.

Hochmuth, G.J. 1991. Fertilizer management for greenhouse vegetables, p. 13-31. In: G.J. Hochmuth (ed.). Florida greenhouse vegetable production handbook. Vol. 3. Univ. of Fla., Inst. of Food and Agr. Serv., Circ. SP 48.

Howard, R.J., J.A. Garland, and W.L. Seaman. 1994. Diseases and pests of vegetable crops in Canada. Can. Phytopathol. Soc. and Entomol. Soc. of Can., Ont., Canada.

Jarvis, W.R. 1997. Managing diseases in greenhouse crops. Amer. Phytopathol. Soc. Press, St. Paul, Minn.

Jovicich, E. 2001. Hydroponic greenhouse pepper in Florida: practices of plant trellising, population, transplant depth, soilless media, and irrigation. MS Thesis, Univ. of Fla., Gainesville.

Jovicich, E. and D.J. Cantliffe. 2001. Trellis system, plant density, and container type can improve fruit yield and plant growth of a greenhouse hydroponic crop. HortScience 36:434. (Abstr.)

Jovicich, E., D.J.Cantliffe, and G.J. Hochmuth. 1999. "Elephant's Foot," a plant disorder in hydroponic greenhouse sweet pepper. Proc. Fla. State Hort. Soc. 112:310-312.

Kozlowski, T.T. 2000. Responses of woody plants to human-induced environmental stresses: Issues, problems, and strategies for alleviating stress. Crit. Rev. Plant Sci. 19:91-170.

Levitt, J. 1972. Responses of plants to environmental stresses. Academic Press, N.Y.

Mangan, F.X., C.H. Vavrina, and J.C. Howell. 2000. Transplant depth affects pepper lodging and maturity. HortScience 35:593-595.

Matta, A. and A. Garibaldi. 1980. Su una necrosi basale del pepperone dovuta a ristagni idrici. Informatore Fitopatologico 11:17-20.

Miyamoto, S., K. Piela, and J. Petticrew. 1985. Salts effects on germination and seedling emergence of several vegetable crops and guayule. Irr. Sci. 3:159-170.

Morató, G.M. 1996. Enfermedades fúngicas, bacterianas y fisiopatías, p. 60-66. In:A. Namesny (ed.). Pimientos. Compendios de Horticultura No. 9 Ediciones de Horticultura, Reus, Spain.

Nuez, F., R. Gil, and J. Costa. 1996. El cultivo de pimientos chiles y ajíes. Mundi-Prensa, Madrid, Spain.

SAS Institute. 1999. SAS/STAT user's guide V8. Vol. 1-3. SAS Inst., Cary, N.C.

Standaert, J.Y., H. Maraite, C. Myttenaere, and J.A. Meyer. 1978. Study of the effect of the salt concentration and the sodium/calcium ratio of the nutrient medium on the susceptibility of tomato to vascular Fusarium disease. Plant Soil 2:269-286.

Tyson, R., B.C Hochmuth, G.J. Hochmuth, E.M. Lamb, and M.S. Sweat. 2001. A decade of change in Florida's greenhouse vegetable industry: 1991-2000. Proc. Fla. State Hort. Soc. 114:280-283

Vavrina, C.S., K.D. Shuler, and P.R. Gilreath. 1994. Evaluating the impact of transplanting depth on bell pepper growth and yield. HortScience 10: 1133-1135.

Vavrina, C.S., S.M. Olson, P.R. Gilreath, and M.L. Lamberts. 1996. Transplant depth influences yield and maturity. HortScience 2:190-192. 